\title{
Spermatogenesis in a Prepubertal Boy
}

\author{
Michael J O'Grady MRCPI ${ }^{1}$ \\ Niamh McGrath MRCPI ${ }^{1}$ \\ Fergal M Quinn MD FRCSI ${ }^{2}$ \\ Michael L Capra FRCPCH \\ Michael B McDermott ${ }^{4}$ \\ Nuala P Murphy ${ }^{1}$ \\ ${ }^{1}$ Department of Endocrinology \& Diabetes, Childrens University Hospital, Temple St. Dublin 1 \\ ${ }^{2}$ Department of Surgery, Our Lady's Childrens Hospital, Crumlin, Dublin 12 \\ ${ }^{3}$ Department of Oncology, Our Lady's Childrens Hospital, Crumlin, Dublin 12 \\ ${ }^{4}$ Department of Histopathology, Our Lady’s Childrens Hospital, Crumlin, Dublin 12
}

A 7.5 year old boy was evaluated for presence of sparse unilateral scrotal hair. No somatic growth spurt, acne, voice changes, adult body odor or enlargement of penis was observed. Testicular volumes were $4 \mathrm{ml}$ on the right and $2 \mathrm{ml}$ on the left. Bone age was 6 years. Basal and stimulated gonadotropins and testosterone were in the pre-pubertal range. Adrenal androgens, 17-

hydroxyprogesterone and a urinary steroid profile were normal. At review six months later, no pubertal progression or growth acceleration was seen. Repeat ultrasound revealed a $2 \times 3 \times 3 \mathrm{~mm}$ hypoechoic mass. He underwent excision and histopathology confirmed the presence of a Leydig cell tumor with evidence of spermatocyte maturation (Figure 1)

Leydig cell tumours are rare accounting for $4-9 \%$ of testicular tumors in pre-pubertal males (1). Unless identified pre-symptomatically they are universally associated with pseudoprecocious puberty mediated by the systemic effects of testosterone. FSH, once thought fundamentally important for spermatogenesis is not universally required (2). Intra-testicular testosterone (I-TT) levels may be 84 -fold increased relative to serum levels (3) and are more critical for spermatogenesis. Accordingly, quantitatively normal spermatogenesis without spontaneous virilisation has been reported in an adult male with very low serum testosterone (4). Spermatocyte maturation in a boy with a Leydig cell tumor without clinical evidence of puberty has been described once previously (5) however no hormone profile was obtained pre-operatively. Our patient had spermatogenesis in the setting of pre-pubertal gonadotrophin and testosterone levels as a result of the paracrine effects of I-TT produced by the tumor. Venous drainage of the testis communicates with posterior scrotal veins via gubernacular veins at the caudal pole (6). Retrograde flow can occur as this system is valveless, permitting exposure of scrotal hair follicles to I-TT, accounting for the presence of scrotal hair on the affected side 


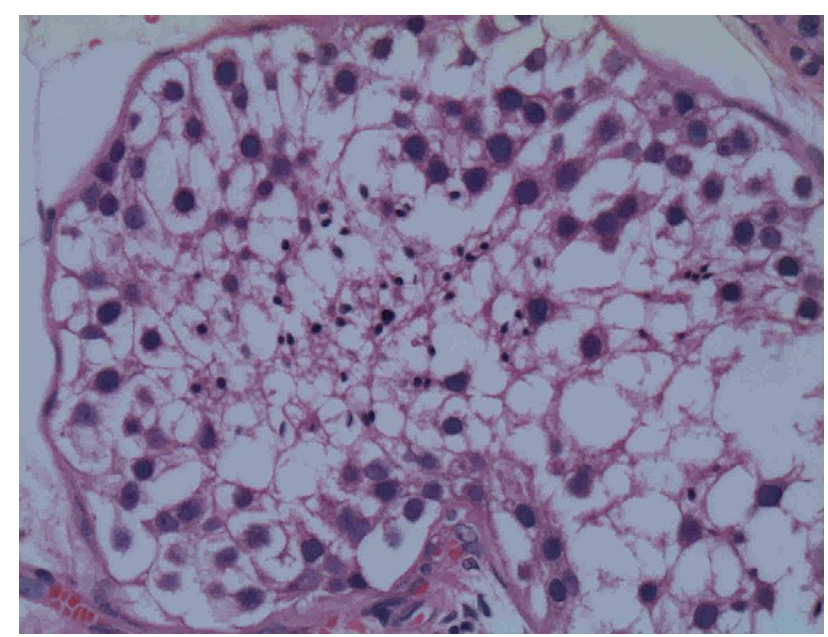

Figure1. Hematoxylinandeosinstainofseminiferoustubule adjacenttotumorshowinggerm cellsinvariousstagesof spermatogenesis.

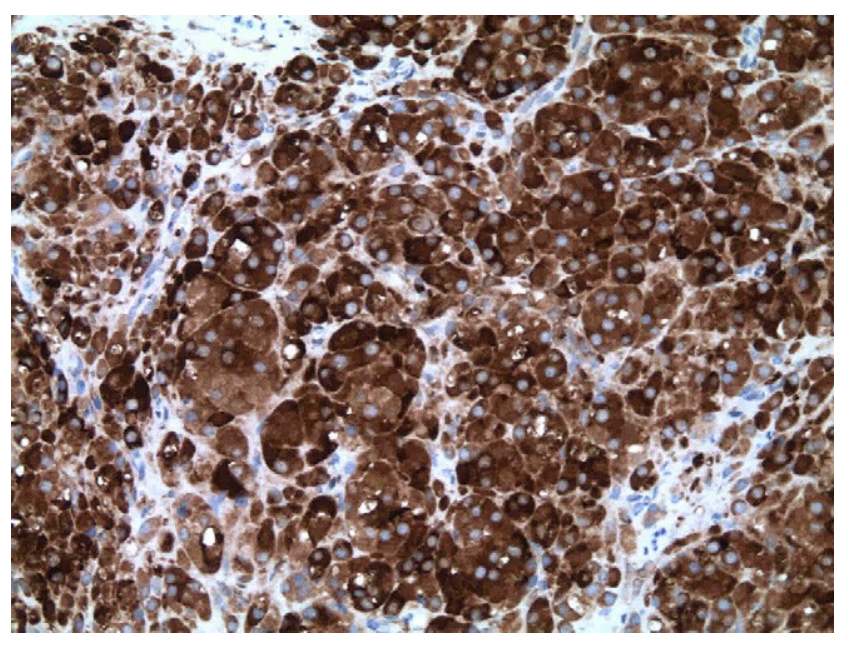

Figure2.Leydig-celladenomawithpositiveimmunohistochemistry for inhibin-a 
Final Peer-Reviewed Author Manuscript

\section{References}

1. Henderson CG, Ahmed AA, Sesterhenn I, Belman AB, Rushton HG. Enucleation for prepubertalleydig celltumor. J Urol. 2006 Aug;176(2):703-5

2. Themmen APN, Huhtaniemi IT. Mutations of gonadotropins and gonadotropin receptors: elucidating the physiology and pathophysiology of pituitary-gonadal function. Endocr Rev. 2000 Oct;21(5):551-83.

3. Coviello AD, Matsumoto AM, Bremner WJ, Herbst KL, Amory JK, Anawalt BD, Sutton PR, Wright WW,

Brown TR, Yan X, Zirkin BR, Jarow JP. Low-dose human chorionic gonadotropin maintains intratesticular testosterone in normal men with testosterone-induced gonadotropin suppression. J ClinEndocrinol Metab. 2005 May;90(5):2595-602.

4. Achard C, Courtillot C, Lahuna O, Méduri G, Soufir JC, Lière P, Bachelot A, Benyounes H, Schumacher M, Kuttenn F, Touraine P, Misrahi M. Normal spermatogenesis in a man with mutant luteinizing hormone. N Engl J Med. 2009 Nov 5;361(19):1856-63.

5. Polepalle SK, Shabaik A, Alagiri M. Leydig cell tumor in a child with spermatocyte maturation and no pseudoprecocious puberty. Urology. 2003 Sep;62(3):551.

6. Mirilas $\mathrm{P}$, Mentessidou A. Microsurgical subinguinalvaricocelectomy in children, adolescents, and adults: surgical anatomy and anatomically jus- tified technique. J Androl 2011; Aug 11;

10.2164/jandrol.111.013052. 